\title{
Surfaces
}

\section{THE CULTURAL DIMENSION}

\section{Terry Cochran}

Volume 2, 1992

ACTES DU COLLOQUE « REPENSER LA CULTURE » ACTS OF THE CONFERENCE "RETHINKING CULTURE"

URI : https://id.erudit.org/iderudit/1065225ar

DOI : https://doi.org/10.7202/1065225ar

Aller au sommaire du numéro

\section{Éditeur(s)}

Les Presses de l’Université de Montréal

ISSN

1188-2492 (imprimé)

1200-5320 (numérique)

Découvrir la revue

Citer ce document

Cochran, T. (1992). THE CULTURAL DIMENSION. Surfaces, 2.

https://doi.org/10.7202/1065225ar
Résumé de l'article

Une étude des rapports entre la culture et la technologie dans les écrits de Benjamin et Gramsci, avec mise en évidence de leur impact sur la notion d'état-nation. d'utilisation que vous pouvez consulter en ligne. 
CONFERENCE PROCEEDINGS

"RETHINKING CULTURE"

THE CULTURAL DIMENSION

Terry Cochran

This paper was originally delivered at the conference Rethinking Culture held at the University of Montreal, April 3-5, 1992. The organizers would like to thank the following sponsors for their financial support:

Social Science Research Council of Canada

Faculty of Arts and Sciences, University of Montreal

Vice Rector for Teaching and Research, University of Montreal

Department of Comparative Literature, University of Montreal

Alitalia 
A study of the relationship between culture and technology in the writings of Benjamin and Gramsci, with special reference to its impact on the notion of the nation state.

\section{RÉSUMÉ}

Une étude des rapports entre la culture et la technologie dans les écrits de Benjamin et Gramsci, avec mise en évidence de leur impact sur la notion d'état-nation.

The process of secularization embodied in the modern state was fundamental for both Benjamin and Gramsci in their attempts to grasp the specificity of the twentieth-century state and culture, although where they placed their emphasis has relevant consequences. For Benjamin, the advent of the state and the secularization it signalled corresponded to, on the one hand, the separation of aura from religion and, on the other, the incipient development of mechanical reproduction in the printing press. Film, and the cultural economy it represents, carries forward in a radical fashion the cultural transformation wrought by mass-produced publishing. Moreover, the Renaissance would have been inconceivable without Gutenberg and his legacy; this conceptual understanding of printing is essential for the essay's argument and underlies the very notion of history it advances:

The enormous changes which printing, the mechanical reproduction of writing, has brought about in literature are well known. However, within the phenomenon which we are here examining from the perspective of world history, print is merely a special, though particularly important, case. (Benjamin, Gesammelte Schriften, 474, E 218-219)

The essay's entire theory of historical understanding is generated in the tension between the print form of mechanical reproduction and its most recent visual form, which is of a different order, even if film and print are linked in Benjamin's particular perspective of universal history. Mass production, when it extends beyond the primitive mass production of printing to annex and determine other cultural domains, is infinitely more than a simple progression and continuation of mass-produced print culture. Print serves as a reference point for twentieth-century mass production only in terms of the historical understanding that attempts to outline the consequences for thought, society, and consciousness of the explosion of 
mass production. The specificity of Benjamin's understanding of this phenomenon, which culminated in his efforts to reappropriate the analytical and cultural categories that emerged as the agents of mass production in the age of printing, has proved to be his most far-reaching insight.

As might be expected, the publishing revolution, in its technical and ideological aspects, also lies at the base of Gramsci's theory of history and goals of cultural intervention. In contrast to Benjamin, the humanist cast to Gramsci's historical enterprise, with its unshakable reliance on the state concept, becomes apparent in the historical role he assigns to the emergence and ongoing impact of printing. Print ushered in a new mode of thinking and permitted the development of logic and argumentation, a necessary component in "creating a new culture on a new social base, which does not have traditions like the old class of intellectuals."[1] The section on "Oratory, Conversation, and Culture" openly reveals the humanist orientation of Gramsci's understanding of history. Print, in contrast to speech, provides the social and intellectual means for the new social group to challenge the dominant cultural order. Over against culture reproduced according to an oral economy, the art of printing revolutionized the whole world of culture, giving to memory an aid of inestimable value and allowing an unprecedented extension of educational activity. Another kind of extension is thus implicit in this study, that of the qualitative as well as quantitative changes (mass extension) that the technical and mechanical [strumentale] development of the organization of culture brought to the way of thinking. (Gramsci, CW, p. 382; p. 1891)

While this passage indisputably echoes Benjamin's formulation, the ultimate divergences between Gramsci's and Benjamin's views derive from more than simply a question of contrasting sensibilities. As always in Gramsci's thought, the core of his understanding concerns the social, political, and cultural possibilities of marginalized or subaltern groups, particularly how these groups move from the condition of being dominated, to forming a coherent unity through cultural means, to achieving some sort of state power. In Gramsci's conception, print culture, in addition to sparking the emergence of a multitude of new institutions and new forms of social consciousness, provides for the first time access to the dominant means of cultural production. For those who have been excluded, speech or the oral economy in general, which because of this exclusion is not based on a prior legitimized knowledge, represents a dead end and the continuation of domination. Gramsci's example for this condition is to the point. The socalled traditional intellectual, who by virtue of social position and all it entails has automatic access to the dominant culture, learns almost by osmosis: "...the children of educated families (famiglie colte) learn to speak "grammatically," in other words they learn the language of educated people (persone colte: persons who have achieved a certain level of culture), without ever having to go through specific and tiring grammatical exercises, unlike the children of parents who speak a dialect or Italian mixed with a dialect" (Gramsci, CW 384; 1892). In this sense, Gramsci's larger conception of history and social change is based on print culture, which for the first 
time extracts the means of cultural production--knowledge spanning centuries and the potential for developing oppositional interpretive strategies, alternative history, and theoretical reasoning--from the absolute monopoly of the dominant groups. Although Gramsci brings a radical perspective to bear on the question of culture, his views of print culture accord with the fundamental precepts of humanist understanding. But these views determine the moral imperatives he reiterates in the notebooks, which often relate to questions of bodily and mental discipline, of concentration, all of which have to do with training oneself to obtain and internalize knowledge that was not readily part of one's psycho-social makeup. While one might be tempted to make an analogy between this philosophical and political position and Gramsci's biography, more pertinent is the fact that this model of social and cultural change, along with the institutions to promote it, represented a theory of knowledge and history upon which a movement could be founded.

Against this background, Benjamin's and Gramsci's differences in regard to print culture and the state can be pinpointed in their respective views of contemporary journalism and, by extension, film, for they both draw analogies between journalism and film. Before radio and television developed to complement or even usurp many of its social functions, journalism played a major role in consolidating and maintaining the polity. Despite Gramsci's own project for an "integral" journalism to build a new culture, he maintained that existing journalism operated according to an oral economy that does not measure up to the reflective thought characterizing the written economy. This view is almost prescient, for the competitors of today's print journalism are all media that clearly belong to orality, whether television, radio, or electronic communication. In Gramsci's words:

[T]he newspaper is very close to oratory and conversation. Newspaper articles are usually written in a hurry, are improvised, and are for the most part like speeches made at public meetings because of the speed with which they are conceived and argued. (CW, p. 381; p. 1890)

Although journalism is obviously part of print culture, it is not on a par with books or journals; in considering the "solidity of a culture," a phrase Gramsci often uses in depicting the historical staying-power of a developed culture, journalism poses only a rudimentary and unreliable stability. Journalism is a necessary component of national culture, but it cannot provide the basis for cultural tradition; like a conversation, it seldom stands the test of time, and a cultural tradition, which serves as the guarantor of and means for producing historical self-consciousness, is at the same time history and access to that history. 
For Benjamin, especially in the context of his concern with the technological means of cultural production and the correlative effects on the sociopolitical order, journalism has a more significant role because it is a mass medium than because it mimics conversation. In fact, journalism is the mass medium that most urgently introduces the question of social, political and cultural agency and, on that basis, is paradigmatic for film:

With the increasing extension of the press, which kept placing new political, religious, scientific, professional, local organs before the readers, an increasing number of readers became writers... Thus, the distinction between author and public is about to lose its basic character. The difference becomes merely functional; it may vary from case to case. At any moment the reader is ready to turn into a writer. (Benjamin, GS, E, 232; G, 493)

Twentieth-century mass media, which Benjamin knew in their incipient form, always subject to control by an overzealous state, reconfigures individual and mass consciousness. The transformed nature of subjectivity, which is briefly described in the fluctuating interaction between individual and public, denies any unilinear notion of "mass communication": the mass is in a way communicating with itself, with each interlocutor occupying alternative poles of this ongoing dialogue. Benjamin would of course deal with this hybrid form of subjectivity in many of his other writings, ranging from his concern with "The Storyteller" to his analysis of E.A. Poe's "The Man of the Crowd" and the concept of the flâneur. According to the logic of technological reproduction, this unstable form of mass agency poses problems for state attempts to mediate and therefore regulate the content and the nature of the mass's communication with itself. Against the totalitarian drive to master and contain this instability with state models inappropriate to the task, Benjamin argued from the perspective of world history and focused on the logic of technology that underlay mass media. Film, the implications of which were only becoming apparent when Benjamin was writing, represented the future of that logic, and today one could extend it to technological media scarcely imaginable in the 1930s, even in the annals of science fiction.

The essay refers to this shift repeatedly, often in different but related realms; the ripple-effect of this series of confrontations between the collapsing hegemony and the drive to establish a new one is discussed in terms of aura, tradition, aesthetics, mass consciousness, mass production, and so on. "Doing justice to these relationships" is the essay's complex, selfproclaimed goal. Film, which unites these disruptive elements into an object of analysis, becomes the vehicle, the point of reference for the unbridgeable break with past modes of cultural production. Standing irrevocably on this 
side of the rupture, it does not lend itself to ritual values, despite the state's attempts to promote the cult of communal legitimacy. Thus because of its precise location in twentieth-century culture and economy, film becomes the "most powerful agent" of historical transformation. Benjamin remarks:

Its social significance, particularly in its most positive form, is inconceivable without its destructive, cathartic aspect, that is, the liquidation of the traditional value of the cultural heritage. (Benjamin, GS, E., 221; 3rd G., 478)

The shift or rupture described here goes beyond merely modifying the cultural tradition or what constitutes it. It strips culture of its traditional value, liquidates it, resulting in a transformation of culture's social function, of the way it is produced and consumed. Not least of all, it called for reconsideration of culture's political significance, the implications of which are even more pertinent today.

On the other hand, Gramsci's underestimation of film, and the mass media it exemplifies, derives from his historical allegiance to the precepts of humanism, in particular to the necessary relationship it endorses between culture and state. Gramsci's own organized efforts to counter the state had a decisive impact on his understanding of how that opposition should take place; although he resolutely fought to redimension culture in the context of this struggle, his conception of mass consciousness and the role of culture owes much to the contemporary state that was the object of his analysis and that determined the terrain of his opposition. Gramsci's brief consideration of film, in addition to bringing into focus important aspects of Benjamin's essay, highlights the terms of state-based theories of culture. For Gramsci, film, like journalism, not only simulates but belongs to an oral economy:

Even today, spoken communication is a means of ideological diffusion which has a speed, and field of action, and an emotional simultaneity far greater than written communication (theatre, cinema and radio, with its loudspeakers in public squares, beat all forms of written communication, including books, periodicals, newspapers and notices pasted on walls)--but superficially, not in depth. (Gramsci, CW, pp. 382-83)

Although the argument seems to be a conceptual one, aligning cinema with speech precisely because it is not the medium for in-depth analysis and criticism, for building a new culture, it also represents a political position drawn from the immediate historical situation. Speech, in the form of oratory, and the mass media that extended its range, was a primary means for fascist consolidation of the state. This aspect of fascist practice is of course vigorously critiqued in Benjamin as well; in this instance, however, 
the reference to speech has to do not with speech itself, not with language, but with nonwritten forms of communication. Unlike the case of journalism versus more reflective and enduring forms of print culture, in which forms of written communication are themselves hierarchized according to their "cultural solidity" or suitability for forming the basis of a new culture, spoken communication belongs to a different order altogether, partly because of its immediacy, partly because of its appeal to emotion. [2]

In other words, Gramsci's political understanding of humanism signals endorsement of the state conception as a model for political and cultural action and determines the scant attention he gives to the sociopolitical implications of mass technology, including cinema. Given Gramsci's unusually progressive views of so-called popular or mass culture, cinema's unheralded role in culture has to do with this conceptual framework of humanism. Superficially, since writing serves as the foundation of nationalcultural tradition, cinema cannot be readily identified as national-specific because it is not written. But cinema's peculiar status seems to depend more on its relationship to its potential audience. This becomes apparent in the way Gramsci defines literary culture, which he refers to as literary art in distinction to other forms of art or culture:

From the viewpoint of cultural history, and thus also of cultural 'creation'..., there exists a difference between literary art and other forms of artistic expression (figurative, musical, orchestral)... [In reference to literary art,] 'verbal' expression has a strictly national-popular-cultural character. (CW $122 ; 2194)$

Here verbal expression does not mean speech or oral communication but rather means verbalization of a text written in a specific national language; the examples offered are reading original texts by Goethe or Dante, which represent literary as opposed to nonliterary culture. Nonliterary culture refers to "art" in the form of a Michelangelo sculpture or a Verdi musical composition, cultural artifacts that admit of experience by those not sharing the culture where they originate. Understanding Goethe in the original German means being German, although Gramsci specifies that this has no racial or ethnic implications: it means simply that one participates or is able to participate in German culture. Moreover, while those nonliterary arts may have a national cultural substratum, they also "travel," in the contemporary language of commercial trade, and as a result they are not intrinsically national-popular-cultural, a designation that has an exclusivity built into it.

The precepts of humanism are well known if not often discussed. Language, which is central to culture and to the collectivity whose togetherness is produced and maintained by that culture, represents the medium for establishing collective unity. And while modern culture, which emerged in 
conjunction with the modern state, requires that the unifying language be written, written language is a necessary but not sufficient condition for state or national culture. Journalism, for example, fulfills the necessary condition-it is written, but it plays only a supportive role in disseminating culture because of its temporal limitations, its inability to transcend its historical moment. In addition to a repository of texts that are language-specific yet not historically limited, the idea of modern cultural unity requires historical justification and a class of intellectuals to determine the course of that history and to adjudicate claims against it; when such a body of texts does not exist, intellectuals must craft them or cobble them together, a charge that in the nineteenth century fell to the philologists. Departing from this historical, political, social, and cultural understanding, Gramsci rightly evolved a model for achieving state power that began with a subaltern group, which for him was the proletariat, that assumed what he termed a "hegemonic attitude" and set out to consolidate a culture designed to provide the group with an awareness of itself as a historical protagonist. This understanding, historically determined in that state and culture have operated in collusion from the outset, a collusion always more blatant in totalitarian regimes, led to predictable conclusions.

Forms of culture that are not anchored in language, specifically written language, exceed the configuration of nation and culture. While in Gramsci's notebooks this is obviously the case for cinema, it is also the case for the socalled figurative arts and for oratory. In effect, oratory provides the paradigm for all nonwritten culture, as for example, when Italians, because of shared historical experience, can follow a non-Italian speaker who speaks in a language other than Italian. For Gramsci, the predominance of nonlinguistic elements affects both the mode of reception and the potential size of the public:

[I]n oratory speech is not the only element: there are also gestures, tone of voice and so on...: gesture in the broad sense, which scans and articulates the wave of feeling and passion.

These observations are indispensable for establishing a cultural politics and they are fundamental for a cultural politics of the popular masses. They explain the international "success" of cinema and, earlier, of opera and music in general. (CW, 123; 2194-95)

As is customary from the perspective of print culture, non-linguistic elements of representation are identified with sentiment, emotion, with aspects of experience that cannot be objectively registered in writing. Cinema is a form of mass culture that speaks to masses both inside and outside the national border; it cannot be wholly grasped by the category of national culture. By contrast, a truly national culture necessarily operates along the axis of inclusion and exclusion; one has to share it in order to have 
access to it. In terms of the epoch of print hegemony, with all the institutions of life and law that accompany it, Gramsci's views of culture and state are accurate and unassailable. The question remains, however, whether cinema, as a drastically different form of mechanical reproduction, can be appropriately evaluated according to the print hegemony and whether it does not signal the advent of an incompatible logic of reproduction.

Although Gramsci relegated cinema to a secondary role in the constitution of cultural hegemony, listing it alongside music, opera, and so on, cinema has a distinction that the other arts cannot replicate: it cannot be separated from the mass production that creates it. This difference, which Gramsci did not remark, becomes the central motif in Benjamin's study precisely because his discussion of film is really an analysis of an entirely new economy of culture:

In the case of films, mechanical reproduction is not, as with literature and painting, an external condition for mass distribution. Mechanical reproduction is inherent in the very technique of film production. This technique not only permits in the most direct way but virtually causes mass distribution. (GS, E., 244 n.7; G., 481-82, n.9)

Many analogies could be drawn between film and painting, on the one hand, and film and printing, on the other. Film, silent film in particular, shares with painting the potential for a transnational audience, whereas with printed material it shares the built-in necessity for a mass audience. But the significance of film, and the mass production it exemplifies, resides elsewhere. Despite attempts by subsequent film criticism to import into film print concepts such as director-auteur, film on the level of creation remains as anonymous as the mass it addresses. The reasons for this, as Benjamin suggests, are as much economic as inherent in the process of making a film. Individuals cannot supply the enormous quantity of capital required to produce a film, a situation that is even truer today than in the 1930s; the extraordinary capital investment in film reflects the needs of mass production generally, although film was arguably the first and most blatantly ideological because it openly challenged the precepts of print culture. Film causes mass distribution in its very logic because mass replication and distribution are necessary for a return on the enormous investment. Just as a film cannot be made without investment in the mechanical means of reproduction, it cannot be viewed without the mediation of technology. Consequently, reception of the film is not based on the customary notion of material possession. Even today, with the growing availability of video cassettes, there is no access to the film, to its series of images, without massive technological mediation; its existence as an object that can be purchased and possessed cannot be equated with that of a painting or book, even though contemporary book production itself has more and more adopted the logic of mass production and distribution. 
The introduction of speech in film, in the first instance, seemed to reassert the power of the state in the new economy of culture and mechanical reproduction. As Benjamin remarks:

With the sound film, to be sure, a setback in its international distribution occurred at first: audiences became limited by language barriers. This coincided with the Fascist emphasis on national interests. It is more important to focus on this connection with Fascism than on this setback, which was soon minimized by synchronization. (ibid)

In Benjamin's conception, technology, by virtue of the further development of its own logic, countered attempts to reimpose national interests. Synchronization, which allowed for repackaging and making accessible the nonlinguistic visual image that is the vehicle of film, created the basis for an even larger mass audience, thereby further challenging hegemonic notions of national culture. This view, coupled with Benjamin's materialist understanding of history, helps explain assertions that his essay would resist appropriation by those who endorsed fascism or the totalitarian state: history was moving inexorably in the opposite direction.

Nevertheless, the new disposition of capital is the aspect of synchronization that is most important for subsequent developments of mass production:

[The sound film] merged new capital from the electrical industry with that of the film industry. Thus, viewed from the outside, the sound film promoted national interests, but seen from the inside it helped to internationalize film production even more than previously. (ibid)

Even though language, with all its national differences, emerged to play a role in film, in the global cultural network it led to a deemphasis of the nation because it represented a shift in the center of gravity from the nation to industries, themselves not necessarily based in the same nations or in nations with wholly compatible interests. The intertwined industries and global interests of today are unfathomable even in the terms of Benjamin's own analyses.

Although Benjamin's later comments indicated a more concretely political understanding of the sound film, the global perspective remained the point of departure. In a letter to Adorno from 9 December 1938, Benjamin writes: 
I see more and more clearly that the launching of the sound film must be regarded as an operation of the cinema industry designed to break the revolutionary primacy of the silent film, which generated reactions that were hard to control and hence politically dangerous.[3]

As in the essay on mechanical reproduction, mass production and film signalled the breakup of cultural and political hegemony based print culture and accompanying nationhood. At the same time, however, since culture functions to stabilize potential disruptions in the social and economic order, a new cultural hegemony has been in the making, one that corresponded to the new importance of industry apart from its national provenance and to new forms of global capital. In an interesting parallel, the journal The Economist describes this transition as it relates to print culture:

In Gutenberg's day, the output from printing presses was both rare and potentially subversive; church and state sought to own the presses, or at least to control what they published. As the technology spread, control became more difficult and was deemed less necessary. Today /pp. 17-18/ publishing is as easily and suitably dealt with by private markets as light bulbs are.[4]

In this century, the transition to mass production has been abrupt and surprisingly complete in the historically rapid expansion to all sectors of economic, social, and political life. This shift to the transnational arena is accelerating at an ever faster pace; fewer and fewer companies or products are really national. And just as Benjamin treated film as an early emblem of this transformation, one could make a similar series of historical claims about the automobile, no less an index of mass production and virtually omnipresent in twentieth-century economy and culture. Yet, as The Economist indicates concerning printing, the decline in overt state intervention corresponds to a growth in the force of the market, an agent no less anonymous than the masses it is claimed to serve. And the market itself, geared to a mass scale, whether in terms of production, circulation, distribution, or capital of socially unmarked provenance, requires a controlled but voracious consumerism, which has become the engine of this new political and cultural economy. And that is the new dimension of culture, the new hegemony it would help to produce, far-removed from quaint and timeworn claims about national and communal traditions.

\section{Terry Cochran}


Surface Page d'Acceuil/Home Page

[1]This passage, along with the passages cited in the following discussion, appears on notebook 16, "Cultural Topics I," pp. 1889-1893. The section is entitled "Oratory, Conversation, Culture" and is a more elaborate version of what appeared in notebook 1 as "Conversation and Culture." Selections from Cultural Writings (henceforth CW) contains a translation of the later version in its entirety (pp. 381-85), whereas the shorter first version is included in Gramsci's Prison Notebooks, volume I, trans. and ed. Joseph A. Buttigieg (New York: Columbia University Press, 1992), pp. 232-234.

[2]This opposition between written and spoken is undoubtedly provoked in part by the immediate historical situation. Hitler, for example, gave the spoken word a privileged place in consolidating mass support for the state (and mass media in general were rigorously controlled under the German state): "The power which has always started the greatest religious and political avalanches in history rolling has from time immemorial been the magic power of the spoken word, and that alone. The broad masses of the people can be moved only by the power of speech" (Mein Kampf [Boston, 1943], p. 107, cited in William L. Shirer, The Rise and Fall of the Third Reich [New York: Ballantine Books, 1983 ed.], p. 46).

[3]Letter from Benjamin to Adorno, 9 December 1938, in Aesthetics and Politics, trans. ed. Ronald Taylor (London: Verso, 1977), p. 140.

[4]The Economist, 7 March 1992, p. 19. 